Supporting information for:

\title{
Synthesis and characterization of electron-deficient pentacenes
}

Christopher R. Swartz, ${ }^{\dagger}$ Joseph E. Bullock, ${ }^{\dagger}$ John E. Anthony, ${ }^{\dagger *}$ Alex C. Mayer, ${ }^{\ddagger}$ George G. Malliaras ${ }^{\ddagger}$

Department of Chemistry, University of Kentucky, Lexington, KY 40506-0055 and Department of Materials Science and Engineering, Cornell University, Ithaca, NY 14853-1501

Anthony@uky.edu

General experimental: All reagents were obtained from the Aldrich Chemical Company (Milwaukee, WI) or Acros Organics (Pittsburgh, PA). Triisopropylsilyl acetylene was purchased from GFS Chemicals (Powell, OH). Tetrahydrofuran and diethyl ether were purified by passage through activated alumina columns under nitrogen. TLC was carried out on MERCK Silica Gel 60 thin layer plates. Silica gel chromatography was performed on Sorbent Technologies silica gel (230-450 mesh). Flame-dried glassware was used in the appropriate steps, and cooled under dry nitrogen. Melting points were recorded on a Thomas-Hoover Capillary Melting Point apparatus, and are uncorrected. UV-Vis absorbance spectra were recorded using a Shimadzu UV-Vis spectrophotometer model UV-2501PC. NMR spectra were recorded on either a Varian Inova $400 \mathrm{MHz} \mathrm{NMR}$, or a Varian Gemini $200 \mathrm{MHz}$ NMR.

9,10-dibromo-6,13-pentacenequinone (2): To a flame-dried round bottom flask cooled under nitrogen at room temperature was added $100 \mathrm{~mL}$ of dry $\mathrm{N}, \mathrm{N}$-dimethylacetamide. The solvent was purged for 30 minutes with nitrogen. 4,5-Dibromo- $\alpha, \alpha, \alpha^{\prime}, \alpha^{\prime}-$ tetrabromo- $o$-xylene $(1.08 \mathrm{~g}, 1.86 \mathrm{mmol})$ was added to the mixture, followed by $1,4-$ anthraquinone $(0.387 \mathrm{~g}, 1.86 \mathrm{mmol}, 1 \mathrm{eq}$.$) , and \mathrm{NaI}(1.42 \mathrm{~g}, 9.48 \mathrm{mmol}, 5.1 \mathrm{eq}$.$) . The$ flask was capped with a rubber septum and bubbler, and stirred vigorously at $90{ }^{\circ} \mathrm{C}$ overnight. The reaction mixture was then filtered, and the crude yellow solid was rinsed with acetone and water. The solid was then triturated with chloroform, filtered, and dried to yield 9,10-dibromo-6,13-pentacenequinone (0.554 g, $1.19 \mathrm{mmol}, 64 \%)$ as an insoluble yellow solid. MS (EI, $70 \mathrm{eV}) 466\left(\mathrm{M}^{+}, 100 \%\right.$, showing expected bromine isotope peake). Anal. calc. C 56.68\%, H 2.16\%. Found: C 56.66\%, H $2.09 \%$.

9,10-dibromo-6,13-bis-tri(isopropylsilylethynyl)pentacene (4); To a flame-dried round bottom flask and stir bar cooled under nitrogen was added $100 \mathrm{~mL}$ of anhydrous ether. Triisopropylsilyl acetylene $(0.66 \mathrm{~mL}, 2.95 \mathrm{mmol}, 5$ eq.) was then added to the flask, followed by $n$-BuLi $(2.46 \mathrm{M}$ in hexanes, $0.72 \mathrm{~mL}, 1.77 \mathrm{mmol}, 3 \mathrm{eq}$.). The mixture was stirred for 30 minutes, and then 9,10-dibromo-6,13-pentacenequinone $(0.275 \mathrm{~g}, 0.590$ mmol, 1 eq.) was added to the mixture, followed by $15 \mathrm{~mL}$ of anhydrous THF. The mixture was stirred for several hours at room temperature, until complete dissolution of the quinone occurred. The mixture was then quenched with wet ether, and the solvent was removed by evaporation. The residue was dissolved in hexanes, and flushed through a silica plug with hexanes to removes excess triisopropylsilyl acetylene. The diol was then removed by flushing the plug with diethyl ether. The solvent was evaporated to yield the crude diol, which was then dissolved in 1:1 $\mathrm{CH}_{3} \mathrm{CN} / \mathrm{THF}$, and stannous chloride dihydrate was added until the mixture turned dark blue. The mixture was stirred for one 
hour at $25{ }^{\circ} \mathrm{C}$, and the blue solid was filtered off, dissolved in $\mathrm{CH}_{2} \mathrm{Cl}_{2}$, and filtered through a silica plug. The solvent was evaporated to yield 9,10-dibromo-6,13-bistri(isopropylsilylethynyl)pentacene $(0.230 \mathrm{~g}, 0.289 \mathrm{mmol}, 49 \%)$ as a dark blue solid which was further purified by recrystallization from dichloromethane. ${ }^{1} \mathrm{H}$ NMR (400 $\left.\mathrm{MHz}, \mathrm{CDCl}_{3}\right) \delta 9.30$ (s, 2H), $9.20(\mathrm{~s}, 2 \mathrm{H}), 8.30$ (s, 2H), 7.98 (dd, J = 6.7 Hz, 3.2 Hz, 2H), $7.44(\mathrm{dd}, J=6.9 \mathrm{~Hz}, 3.2 \mathrm{~Hz}, 2 \mathrm{H}), 1.40(\mathrm{~s}, 42 \mathrm{H}) .{ }^{13} \mathrm{C}$ NMR $\left(100 \mathrm{MHz} \mathrm{CDCl}_{3}\right) \delta 132.7$, 132.6, 131.1, 130.9, 130.7, 128.7, 126.5, 126.4, 125.9, 122.3, 118.8, 108.1, 104.2, 19.0, 11.6. MS (EI, $70 \mathrm{eV}) 796\left(\mathrm{M}^{+}, 100 \%\right)$. Anal. calc. C 66.32\%, H 6.57\%. Found: C $66.80 \%, \mathrm{H} 6.35 \%$. MP: $258{ }^{\circ} \mathrm{C}$.

2,3-dicyano-6,13-bis-(triisopropylsilylethynyl)pentacene (15): To a flame-dried threaded sealed tube reactor cooled under nitrogen was added $50 \mathrm{~mL}$ of dioxane, which was sparged with nitrogen for 20 minutes at room temperature. After sparging, 2,3dibromo-6,13-bis-tri(isopropylsilylethynyl)pentacene $(0.380 \mathrm{~g}, 0.477 \mathrm{mmol}, 1$ eq.) was added to the mixture, followed by $\mathrm{Pd}\left(\mathrm{PPh}_{3}\right)_{4}(0.110 \mathrm{~g}, 0.095 \mathrm{mmol}, 0.2 \mathrm{eq}$.$) , and \mathrm{CuCN}$ (0.256 g, $2.86 \mathrm{mmol}, 6$ eq.). The vessel was then capped and heated in an oil bath at 120 ${ }^{\circ} \mathrm{C}$ for 14 hours. The mixture was then cooled to room temperature, diluted with ethyl acetate, and filtered through a silica plug. The solvent was evaporated to yield a crude blue-green solid. The product was purified by silica column chromatography $(1: 1$ hexanes $/ \mathrm{CH}_{2} \mathrm{Cl}_{2}$ ) to yield 2,3-dicyano-6,13-bis-tri(isopropylsilylethynyl)pentacene $(0.120$ $\mathrm{g}, 0.160 \mathrm{mmol}, 33 \%)$ as a blue-green solid. The product was recrystallized from toluene to yield blue needles. ${ }^{1} \mathrm{H}$ NMR $\left(400 \mathrm{MHz} \mathrm{CDCl}_{3}\right) \delta 9.40(\mathrm{~s}, 2 \mathrm{H}), 9.38(\mathrm{~s}, 2 \mathrm{H}), 8.48$ (s, 2H), $8.03(\mathrm{dd}, J=6.6 \mathrm{~Hz}, 3.1 \mathrm{~Hz}, 2 \mathrm{H}), 7.52(\mathrm{dd}, J=6.6 \mathrm{~Hz}, 3.1 \mathrm{~Hz}, 2 \mathrm{H}), 1.40(\mathrm{~m}, 21 \mathrm{H})$. ${ }^{13} \mathrm{C}$ NMR $\left(100 \mathrm{MHz}, \mathrm{CDCl}_{3}\right) \delta 138.8,133.2,131.5,131.3,129.7,128.9,128.7,127.1$, 126.8, 120.1, 116.2, 109.7, 108.1, 103.4, 19.0, 11.6. MS (EI, 70 eV) $688\left(\mathrm{M}^{+}, 100 \%\right)$. Anal. calcd. C 80.17\%, H 7.60\%, N 4.06\%. Found: C 80.05\%, H 7.38\%, N 3.94\%. MP: $327^{\circ} \mathrm{C}$.

2,3,9,10-tetrabromo-6,13-pentacenequinone (3): To a flame-dried round bottom flask cooled under nitrogen was added $100 \mathrm{~mL}$ of dimethylacetamide. The solvent was sparged for 30 minutes with nitrogen. 4,5-Dibromo- $\alpha, \alpha, \alpha$,,$\alpha^{\prime}$-tetrabromo- $o$-xylene $(10 \mathrm{~g}, 17.26$ mmol) was added to the flask with vigorous stirring, followed by $p$-benzoquinone $(0.933$ g, $8.63 \mathrm{mmol}, 0.5$ eq.), and sodium iodide (13.19 g, $88.02 \mathrm{mmol}, 5.1$ eq.). The mixture was then capped with a rubber septum and bubbler and was stirred at $90{ }^{\circ} \mathrm{C}$ for 48 hours. The mixture was then filtered, and the yellow-brown solid was rinsed with acetone and water. The solid was then triturated with chloroform, filtered, and dried under vacuum to yield 2,3,9,10-tetrabromo-6,13-pentacenequinone as a yellow solid (1.55 g, $2.28 \mathrm{mmol}$, 29\%). MS (MALDI): $623\left(\mathrm{M}^{+}, 100 \%\right)$. Anal. calc. C 42.35\%, H 1.29\%. Found: C $42.03 \%, \mathrm{H} 1.48 \%$.

2,3,9,10-tetrabromo-6,13-bis-(triisopropylsilylethynyl)pentacene (5): To an ovendried round-bottom flask cooled under nitrogen was added $80 \mathrm{~mL}$ of anhydrous ether at 0 ${ }^{\circ} \mathrm{C}$. Triisopropylsilylacetylene $(2.41 \mathrm{~mL}, 10.75 \mathrm{mmol}, 5$ eq. $)$ was added to the flask, followed by $n$-butyllithium $(2.62 \mathrm{~mL}, 6.54 \mathrm{mmol}, 3$ eq. $)$. The mixture was stirred for 30 minutes, and then 2,3,9,10-tetrabromo-6,13-pentacenequinone (1, $2.15 \mathrm{mmol}, 1$ eq.) was added to the mixture, followed by $30 \mathrm{~mL}$ of anhydrous tetrahydrofuran. The mixture was 
then removed from the ice bath, and allowed to warm to room temperature overnight. The reaction was quenched with wet diethyl ether, and evaporated to dryness. The crude oil was dissolved in hexanes, and flushed with hexanes on a silica plug to remove excess triisopropylsilylacetylene. The plug was then flushed with ethyl acetate to remove the diol. After the solvent was evaporated, the diol was dissolved in $\mathrm{THF} / \mathrm{CH}_{3} \mathrm{CN}$, and stannous chloride was added until the mixture turned a dark blue color. The reaction was stirred for one hour at room temperature, and then the solvent was evaporated. The residue was dissolved in $1: 1$ hexanes $/ \mathrm{CH}_{2} \mathrm{Cl}_{2}$ and filtered through a silica plug. The solvent was evaporated to yield 2,3,9,10-tetrabromo-6,13-bis-tri(isopropyl silylethynyl)pentacene $(1.31 \mathrm{~g}, 0.419 \mathrm{mmol}, 64 \%)$ as a dark blue solid. The solid was recrystallized from 1,2-dichloroethane to yield blue needles. ${ }^{1} \mathrm{H}-\mathrm{NMR}$ (400 $\mathrm{MHz}, \mathrm{CDCl}_{3}$ ) $\delta 9.20(\mathrm{~s}, 4 \mathrm{H}), 8.25(\mathrm{~s}, 4 \mathrm{H}), 1.4(\mathrm{~s}, 42 \mathrm{H}) .{ }^{13} \mathrm{C} \mathrm{NMR}\left(100 \mathrm{MHz}, \mathrm{CDCl}_{3}\right) \delta 132.7,131.4$, 131.1, 126.0, 122.8, 119.2, 108.9, 103.8, 19.0, 11.9. MS (EI, $70 \mathrm{eV}) 954.5\left(\mathrm{M}^{+}, 100 \%\right)$. Anal. calc. C 55.35\%, H 5.27\%. Found: C 55.86\%, H 5.40\%. MP: $332{ }^{\circ} \mathrm{C}$.

2,3,9,10-tetracyano-6,13-bis-tri(isopropylsilyl)ethynylpentacene (16): To a flamedried pyrex tube with glass-thread mouth was added $50 \mathrm{~mL}$ of DMF, and the solvent was sparged with nitrogen for 30 minutes. 2,3,9,10-tetrabromo-6,13-bistri(isopropylsilyl)ethynylpentacene $(0.300 \mathrm{~g}, 0.314 \mathrm{mmol})$ was added to the flask, followed by $\mathrm{Pd}\left(\mathrm{PPh}_{3}\right)_{4}(0.073 \mathrm{~g}, 0.063 \mathrm{mmol}, 2$ eq.), and $\mathrm{CuCN}$ (0.377 g, $3.76 \mathrm{mmol}, 12$ eq.). The flask was capped and placed inside a microwave reactor. The reaction was stirred and heated at $140^{\circ} \mathrm{C}$ for 18 minutes (power $=150 \mathrm{~W}$ ). The mixture was allowed to cool to room temperature, and was then diluted with $\mathrm{CH}_{2} \mathrm{Cl}_{2}$. The organic layer was then added to a $50 \%(\mathrm{v} / \mathrm{v}) \mathrm{NH}_{4} \mathrm{OH} / \mathrm{H}_{2} \mathrm{O}$ solution, and the organic layer was then extracted several times with ice water, dried over $\mathrm{MgSO}_{4}$, filtered, and the solvent removed to yield a crude green solid. The solid was purified by column chromatography ( silica / $\mathrm{CH}_{2} \mathrm{Cl}_{2}$ ) to yield 2,3,9,10-tetracyano-6,13-bis-tri(isopropylsilyl)ethynylpentacene $(0.095 \mathrm{~g}, 0.129$ mmol, $41 \%$ ) as a blue solid. The material was recrystallized from $\mathrm{CH}_{2} \mathrm{Cl}_{2}$ to yield blue needles. ${ }^{1} \mathrm{H}-\mathrm{NMR}\left(200 \mathrm{MHz}, \mathrm{CDCl}_{3}\right) 9.50(\mathrm{~s}, 4 \mathrm{H}), 8.50(\mathrm{~s}, 4 \mathrm{H}), 1.60(\mathrm{~s}, 6 \mathrm{H}), 1.40(\mathrm{~s}$, $36 \mathrm{H}) .{ }^{13} \mathrm{C}-\mathrm{NMR}\left(50 \mathrm{MHz}, \mathrm{CDCl}_{3}\right) \delta 138.6,132.9,130.1,129.9,121.6,115.8,112.49$, 109.4, 102.4, 19.1, 11.6. Anal. calc. C 78.00\%, H 6.81\%, N 7.58\%. Found C 77.86\%, H $6.63 \%, \mathrm{~N} 7.03 \%$. MP: $355^{\circ} \mathrm{C}$.

1,2-Bis-bromomethyl-3,4,5,6-tetrafluoro-benzene (8): $5.5 \mathrm{~g}$, (26 mmol) of tetrafluoro benzenedimethanol ${ }^{1}$ was added to $200 \mathrm{~mL}$ concentrated hydrobromic acid. The mixture was allowed to reflux overnight, by which time all solid had disappeared and an oil formed at the bottom of the flask. The mixture was diluted with water and extracted with hexanes. Drying and evaporation gave 8 as a yellow oil (8.7 g, $99 \%$ yield). MS (EI, 70 eV) $336\left(\mathrm{M}^{+}\right), 255\left(\mathrm{M}^{+}\right.$- Br). ${ }^{1} \mathrm{H}-\mathrm{NMR}\left(400 \mathrm{MHz}^{\mathrm{CDCl}}{ }_{3}\right) 4.63$ (s, 4H).

1,2,3,4-tetrafluoro-pentacene-6,13-dione (9): Dibromide 8 (4.7 g, 14.0 mmol), 1,4anthraquinone $(2.91 \mathrm{~g}, 14.0 \mathrm{mmol})$, and $\mathrm{KI}(15.56 \mathrm{~g}, 93.7 \mathrm{mmol})$, were dissolved in dry DMF and stirred in a vessel capped with a threaded Teflon plug at $110{ }^{\circ} \mathrm{C}$ for two days. The reaction mixture was cooled to room temperature and filtered, and the collected solid

1 Coe, P. L.; Croll, B. T.; Patrick, C. R. Tetrahedron 1967, 23, 505. 
washed with methylene chloride to remove any soluble organic contaminants. The dark solid was then stirred in an Erlenmeyer flask with water to remove excess KI. The remaining brown solid was filtered once again, washed with acetone and dried in air to yield $4.0 \mathrm{~g}$ of an insoluble powder (75\% yield). MS (EI, $70 \mathrm{eV}) 380\left(\mathrm{M}^{+}\right)$.

1,2,3,4-tetrafluoro-6,13-bis-(triisopropylsilylethynyl) pentacene (13): In a dried flask triisopropylsilyl acetylene $(3.07 \mathrm{~g}, 16.84 \mathrm{mmol})$ was dissolved in dry hexanes. A $2.5 \mathrm{M}$ solution of n-butylithium $(5.9 \mathrm{~mL}, 14.7 \mathrm{mmol})$ was added slowly under dry nitrogen, and the mixture allowed to stir for thirty minutes. Pentacenequinone $\mathbf{9}$ was added quickly, and the mixture was stirred at room temperature for $5 \mathrm{~d}$, until all of the quinone had dissolved. The reaction mixture was quenched with $10 \% \mathrm{HCl}$, which caused a brown precipitate to form. The precipitate was filtered and dissolved in acetonitrile. Tin (II) chloride $(2.85 \mathrm{~g}, 12.63 \mathrm{mmol})$ was added to the solution and it was heated at reflux overnight under nitrogen. The light-blue precipitate was filtered and washed with acetone. Recrystallizing twice from hexanes gave dark blue needles of $\mathbf{1 3}(0.6 \mathrm{~g}, 20 \%$ yield). ${ }^{1} \mathrm{H} \mathrm{NMR}\left(400 \mathrm{MHz}, \mathrm{CDCl}_{3}\right.$ ) $\delta 9.52$ (s, $\left.2 \mathrm{H}\right), 9.28$ (s, $\left.2 \mathrm{H}\right), 7.97$ (dd, $2 \mathrm{H}, \mathrm{J}=3.6$ $\mathrm{Hz}, 6.8 \mathrm{~Hz}), 7.44(\mathrm{dd}, 2 \mathrm{H}, \mathrm{J}=3.2 \mathrm{~Hz}, 6.8 \mathrm{~Hz}), 1.35$ (m, $42 \mathrm{H})$. MS (EI, $70 \mathrm{eV}) 710$ $\left(100 \%, \mathrm{M}^{+}\right), 691\left(20 \%, \mathrm{M}^{+}-\mathrm{F}\right)$. Anal. Calcd. for $\mathrm{C}_{44} \mathrm{H}_{50} \mathrm{~F}_{4} \mathrm{Si}_{2}:$ C $74.32 \%, \mathrm{H} 7.08 \%$. Found: C $74.23 \%$, H 7.06\%. M.P. $275^{\circ} \mathrm{C}$.

5,6,7,8-tetrafluoro-1,4-anthraquinone (11): In a dry flask, 1,2-bis-bromomethyl3,4,5,6-tetrafluoro-benzene 8 (2.0 g, $6.0 \mathrm{mmol})$, benzoquinone (0.64 g, $6.0 \mathrm{mmol})$, and KI (6.6 g, $40.0 \mathrm{mmol})$, were dissolved in dry DMF $(60 \mathrm{~mL})$. The mixture was heated at $110{ }^{\circ} \mathrm{C}$ for two days. The dark mixture was cooled to room temperature and extracted with ice water and methylene chloride. The organic layer was dried and all organic solvents were evaporated. The product was isolated on a plug eluted with 1:1 hexanes/methylene chloride to yield a yellow solid (10) which turned brown on exposure to air overnight to yield quinone 11 (1.0 g, $60 \%$ yield), and was used without further purification in the next reaction step. ${ }^{1} \mathrm{H}$ NMR $\left(400 \mathrm{MHz}, \mathrm{CDCl}_{3}\right) \delta 6.82(\mathrm{~s}, 2 \mathrm{H}), 3.74(\mathrm{~s}$, $2 \mathrm{H})$. MS (EI, $70 \mathrm{eV}) 280\left(100 \%, \mathrm{M}^{+}\right)$.

1,2,3,4,8,9,10,11-octafluoro-6,13-pentacene quinone (12): In a dried, round bottom flask, 5,6,7,8-tetrafluoro-1,4-anthraquinone $\mathbf{1 1}(3.15 \mathrm{~g}, 11.3 \mathrm{mmol})$, 1,2-bisbromomethyl-3,4,5,6-tetrafluoro-benzene 8 (3.78 g, $11.3 \mathrm{mmol})$, and KI (12.51 g, 75.4 mmol) were dissolved in dry DMF $(60 \mathrm{~mL})$ and heated at $110{ }^{\circ} \mathrm{C}$ for two days. The workup was identical to that described for 1,2,3,4-tetrafluoro-6,13-pentacenequinone 9, yielding a highly insoluble light yellow-green solid (1.17 g, $23 \%$ yield). MS (EI, $70 \mathrm{eV}$ ) $458\left(100 \%, \mathrm{M}^{+}\right), 441\left(70 \%, \mathrm{M}^{+}-\mathrm{F}\right), 422\left(40 \%, \mathrm{M}^{+}-2 \mathrm{~F}\right)$.

1,2,3,4,8,9,10,11-tetrafluoro-bis-(triisopropylsilylethynyl) pentacene ( 14 ): The procedure used to make tetrafluoro compound 13 was used on $1.13 \mathrm{~g}(2.5 \mathrm{mmol})$ of 12 to prepare 14. The crude product was recrystallized twice from methylene chloride to give dark square plates $\left(0.58 \mathrm{~g}, 30 \%\right.$ yield). ${ }^{1} \mathrm{H} \mathrm{NMR}\left(400 \mathrm{MHz}, \mathrm{CDCl}_{3}\right) \delta 9.65(\mathrm{~s}, 4 \mathrm{H}), 1.41$ $(\mathrm{s}, 42 \mathrm{H})$. MS (EI, $70 \mathrm{eV}) 782\left(30 \%, \mathrm{M}^{+}\right), 638\left(30 \%, \mathrm{M}^{+}-2(i-\mathrm{Pr})\right.$ and $\left.3 \mathrm{~F}\right)$. Anal. Calcd. for $\mathrm{C}_{44} \mathrm{H}_{46} \mathrm{~F}_{8} \mathrm{Si}_{2}: \mathrm{C} 67.89 \%$, H 5.92\%. Found: C 68.37\%, H 5.99\%. M.P. $279{ }^{\circ} \mathrm{C}$. 


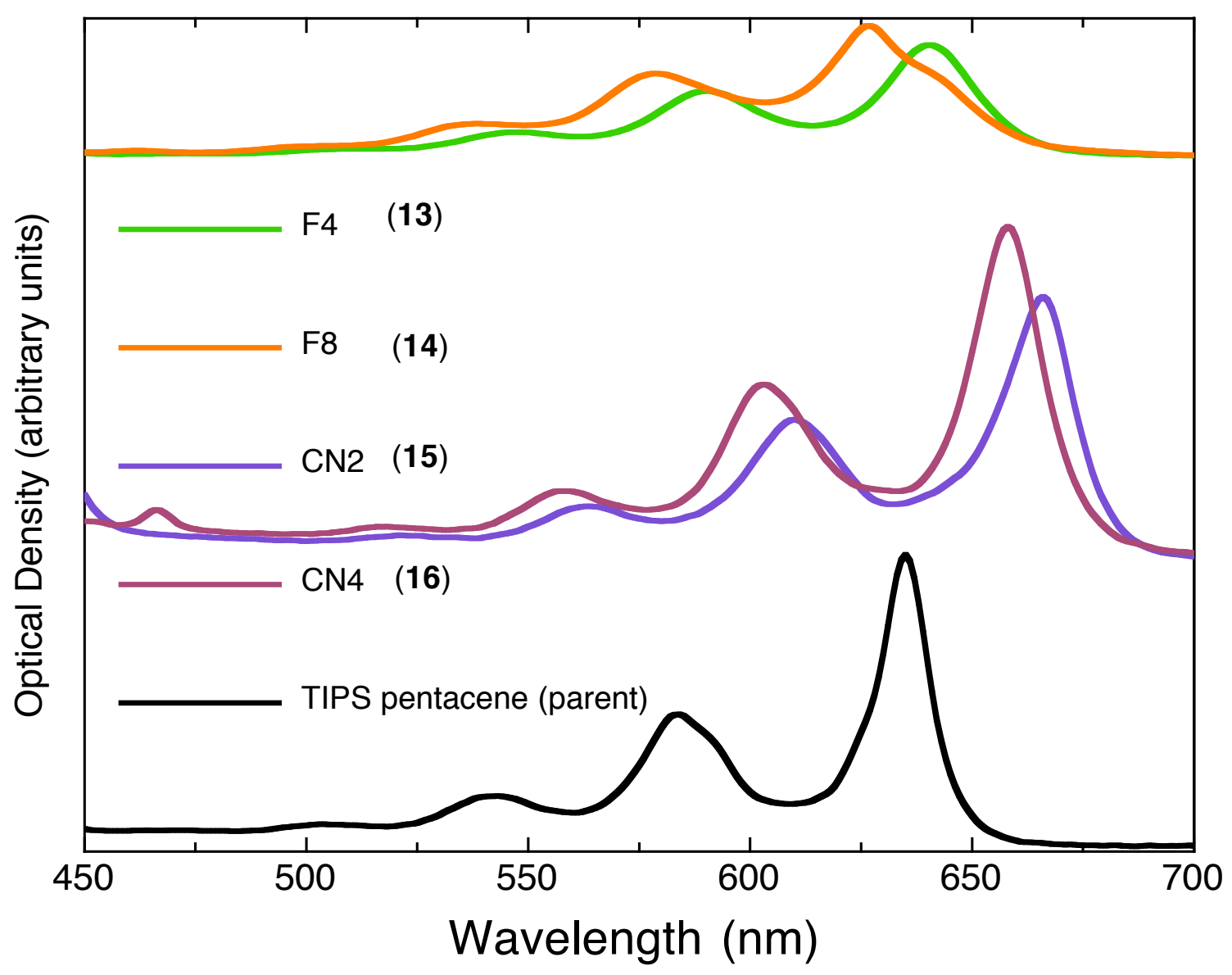

UV-Vis spectra for compounds $\mathbf{1 3}$ - 17 .

Numerical UV-Vis data for $\mathbf{1 3}-\mathbf{1 6}$ :

Tetrafluoro $13 \lambda_{\text {nm }}(\varepsilon)$ in $\mathrm{CH}_{2} \mathrm{Cl}_{2}$ : 640 (15418), 590 (10008), 546.5 (4928), 440 (4184), 416 (3903), 392 (4041), 349 (sh, 9569), 327 (sh, 27715), 310 (153903), 270.5 (21075)

Octafluoro $14 \lambda_{\text {nm }}$ ( $\varepsilon$ ) in $\mathrm{CH}_{2} \mathrm{Cl}_{2}$ : 635 (13090), 586 (9045), 544.5 (4415), 505.5 (2337), 440 (2382), 417 (2485), 392 (3131), 348 (sh, 7781), 326 (sh, 22111), 308 (174045), 269 (15452)

Dicyano $15 \lambda_{\text {nm }}$ ( $\varepsilon$ ) in $\mathrm{CH}_{2} \mathrm{Cl}_{2}$ : 675 (11684), 621 (7731), 570.5 (3612), 527.5 (1963), 445 (4391), 417 (5782), 339 (113612), 293 (39210)

Tetracyano $16 \lambda_{\mathrm{nm}}$ ( $\varepsilon$ ) in $\mathrm{CH}_{2} \mathrm{Cl}_{2}$ : 668 (8980), 613 (5788), 566.5 (3418), 471 (3369), 382 (sh, 8532), 342 (116236), 327.5 (sh, 31270), 275.5 (13753) 